Юй Жуйхэн, Еланцева О. П. Антияпонская война китайского народа (1937-1945 гг.) на страницах газеты Тихоокеанского флота «Боевая вахта»

УДК 94(510:520)"1937/1945"(093.3)

DOI dx.doi.org/10.24866/1813-3274/2020-2/91-106

Юй Жуйхэн ${ }^{1}$, Дальневосточный федеральный университет, г. Владивосток, Россия

E-mail: iui.zhu@students.dvfu.ru

О. П. Еланцева ${ }^{2}$, Дальневосточный федеральный университет,

г. Владивосток, Россия

E-mail: elantseva.op@dvfu.ru

\title{
АНТИЯПОНСКАЯ ВОЙНА КИТАЙСКОГО НАРОДА (1937-1945 ГГ.) НА СТРАНИЦАХ ГАЗЕТЫ ТИХООКЕАНСКОГО ФЛОТА «БОЕВАЯ ВАХТА»
}

Аннотащия. Рассматривается освещение событий антияпонской войны китайского народа (1937-1945 гг.) газетой Тихоокеанского флота «Боевая вахта» (г. Владивосток). В это время Советский Союз предоставлял Китаю не только военную, материальную помощь, но и оказывал моральную поддержку, в том числе через средства массовой информации, рассказывая о национально-освободительной войне китайского народа. Отмечено, что во время войны Гоминьдан и Коммунистическая партия Китая создали антияпонский национальный единый фронт и объединились против японских захватчиков. Китайский народ мужественно боролся за свою свободу и национальную независимость. Газета высоко оценила деятельность Коммунистической партии Китая и её борьбу с японскими захватчиками в трудных условиях. Но во время антияпонской войны правительство Гоминьдана не отказывалось от антикоммунистической политики. Газета критиковала коррупцию в правительстве Гоминьдана и его неспособность вести активные действия в середине и конце войны; публиковала факты, как Ван Цзинвэй вступил в сговор с японскими захватчиками. 26 января 1940 г. «Боевая вахта» приводила текст соглашения, подписанного между Ван Цзинвэем и японцами. Подчёркивается, что газета «Боевая вахта» цитировала сообщения из китайских газет, то есть показыва-

\footnotetext{
${ }^{1}$ Жуйхэн Юй, выпускник Института науки и техники Хубэйского университета автомобильной промышленности (г. Шиянь), КНР; магистрант-историк Департамента истории и археологии Школы искусств и гуманитарных наук, Дальневосточный федеральный университет, г. Владивосток, Россия.

${ }^{2}$ Ольга Павловна Еланцева, доктор исторических наук, профессор, Школа искусств и гуманитарных наук, Дальневосточный федеральный университет, г. Владивосток, Россия.

Для цитирования: Юй Жуйхэн, Еланцева О. П. Антияпонская война китайского народа (1937-1945 гг.) на страницах газеты Тихоокеанского флота «Боевая вахта» // Азиатско-Тихоокеанский регион: экономика, политика и право. 2020. № 2. С. 91-106.
}

(C) Юй Жуйхэн, Еланцева О. П., 2020 
ла дальневосточникам, как китайские газеты осуждают предательские действия марионеточного режима Ван Цзинвэя. «Боевая вахта» в подробностях сообщала также и о причинах, процессе и результате советско-японской войны - последних военных действиях в рамках Второй мировой войны.

Ключевые слова: газета «Боевая вахта» (г. Владивосток), публикации, национально-освободительная война китайского народа, Гоминьдан, Коммунистическая партия Китая, Ван Цзинвэй, сговор с японскими захватчиками, марионеточный режим, советско-японская война, последние военные действиях в рамках Второй мировой войны.

Yu Ruiheng ${ }^{1}$, Far Eastern Federal University, Vladivostok, Russia

E-mail: iui.zhu@students.dvfu.ru

O. P. Elantseva ${ }^{2}$, Far Easter Federal University, Vladivostok, Russia

E-mail: elantseva.op@dvfu.ru

\section{ANTI-JAPANESE WAR OF THE CHINESE PEOPLE (1937-1945) ON THE PAGES OF THE PACIFIC FLEET'S BATTLE WATCH NEWSPAPER}

Abstract. The coverage of the main events of the anti-Japanese war of the Chinese people (1937-1945) by the Pacific Fleet newspaper Battle Watch (Vladivostok) is considered. At that time, the Soviet Union provided not only military and material assistance to China, but also provided moral support, including through the media, telling about the national liberation war of the Chinese people. It is noted that during the war the Kuomintang and the Chinese Communist Party created an anti-Japanese national united front and united against the Japanese invaders. The Chinese people fought bravely for their freedom and national independence. The newspaper praised the activities of the Chinese Communist Party and its struggle with the Japanese invaders in difficult conditions. But during the anti-Japanese war, the Kuomintang government did not abandon anticommunist policies. The newspaper criticized corruption in the Kuomintang government and its inability to take active steps in the middle and end of the war; published the facts as Wang Jingwei colluded with the Japanese invaders. On January 26, 1940, Battle Watch cited the text of the agreement signed between Wang Jingwei and the Japanese. It is em-

\footnotetext{
${ }^{1}$ Ruiheng Yu, undergraduate of the School of Arts and Humanities, Far Eastern Federal University, Vladivostok, Russia.

${ }^{2}$ Olga P. Elantseva, Doctor of Historical Sciences, Professor, School of Arts and Humanities, Far Eastern Federal University, Vladivostok, Russia.

For citing: Yu Ruiheng, Elantseva O. P. Anti-Japanese War of the Chinese People (1937-1945) on the pages of the Pacific Fleet's Battle Watch newspaper // PACIFIC RIM: Economics, Politics, Law. 2020. No 2. P. 91-106.
} 
phasized that the Battle Watch newspaper quoted messages from Chinese newspapers, that is, it showed the Far East how Chinese newspapers condemn the treacherous actions of the puppet regime of Wang Jingwei. The Battle Watch also reported in detail about the causes, process and result of the Soviet - Japanese war - the latest military operations in the framework of World War II.

Keywords: Battle Watch newspaper (Vladivostok), publications, the national liberation war of the Chinese people, the Kuomintang, the Chinese Communist Party, Wang Jingwei, conspiracy with the Japanese invaders, puppet regime, the Soviet-Japanese war, recent military operations within World War II.

В 2020 г. отмечается 75-летие окончания Второй мировой войны и её составной части - антияпонской войны китайского народа (1937-1945 гг.). «Мукденский инцидент» 18 сентября 1931 г. явился отправной точкой в выступлениях китайского народа против японских захватчиков [1], усилившийся под влиянием события, имевшего место в марте 1932 г. Тогда в Чанчуне было провозглашено марионеточное государство Маньчжоу-Го ${ }^{1}$. По плану Японии марионеточный режим устанавливался на всех уровнях: политическом, военном, экономическом, культурном и др.; учреждались новые жандармские, законодательные, специальные органы. До осени 1945 г. на территории Китая не прекращалась жестокая, кровопролитная война против Японии. Газета «Правда» отмечала, что Советский Союз и Китай находились в одном лагере войны против гнёта агрессоров на западе и на востоке [2].

По некоторым оценкам, потери китайской стороны в антияпонской войне составили около 35 млн чел. Эта война стала не только народной, священной по своему характеру, но и первой победоносной войной китайского народа. В современной китайской историографической традиции её принято называть войной сопротивления Японии, войной китайского народа против японской агрессии, японокитайской войной, мировой антияпонской войной. Война охватила значительные территории Китая: провинции Ляонин, Цзилинь, Хэйлунцзян и др.

Антияпонская война послужила важным информационным поводом, который позволил советской периодической печати широко освещать развитие событий в Китае по упрощённой схеме военного противостояния, подчас оставляя в стороне сложное и противоречивое взаимодействие различных сил политического процесса, но при этом неукоснительно соблюдая установку, данную И. В. Сталиным. И. В. Сталин требовал: «Пусть «Правда» ругает вовсю японских оккупантов,

\footnotetext{
${ }^{1}$ Марионеточное государство Маньчжоу-Го, или Маньчжоу-Диго, образованное японской военной администрацией на оккупированной Японией территории Маньчжурии; существовало с 1 марта 1932 г. по 19 августа 1945 г. Граничило с Японской империей, Монголией, СССР, Мэнцзяном и Китайской Республикой.
} 
Лигу наций как орудие войны, а не мира, Пакт Келлога как орудие оправдания оккупации, Америку как сторонницу дележа Китая. Пусть кричит «Правда» вовсю, что империалистические пацифисты Европы, Америки и Азии делят и порабощают Китай.

«Известия» должны вести ту же линию, но в умеренном и архи осторожном тоне. Умеренный тон для «Известий» абсолютно необходим» [3]. Статьи ключевых центральных общественно-политических изданий («Правда», «Известия») перепечатывали или давали в сокращении многие региональные газеты Советского Союза, в том числе «Боевая вахта» (г. Владивосток).

Цель данной статьи - раскрыть освещение «Боевой вахтой», краснофлотской газетой ТОФ, событий антияпонской войны китайского народа. Известно, что в это время Советский Союз предоставлял Китаю не только военную, материальную помощь, но и оказывал моральную поддержку, в том числе через средства массовой информации, рассказывая о событиях в Китае, о национально-освободительной войне китайского народа. Каким же образом, в каких формах газета «Боевая вахта» сообщала о событиях Китае? Какую позицию отражала её информация о Китае? Данные вопросы будут проанализированы в статье.

«Боевая вахта» на своих страницах знакомила читателей с грандиозными преобразованиями, происходившими в СССР, и особенно на его Дальнем Востоке; она сообщала зарубежные новости, в том числе давала информацию о событиях в Китае.

Таблицьа 1

\section{Рубрики «Боевой вахты», в которых публиковались материалы о военных событиях в Китае (1940-1944 гг.)}

\begin{tabular}{|c|c|c|c|}
\hline № & Название рубрики & $\begin{array}{l}\text { Количество } \\
\text { публикаций }\end{array}$ & За какое время \\
\hline 1. & $\begin{array}{l}\text { Военные действия } \\
\text { в Китае }\end{array}$ & 39 & 5 января 1940 г.- 15 сентября 1944 г. \\
\hline 2. & Японо-китайская война & 55 & 6 января 1942 г. - 19 октября 1943 г. \\
\hline 3. & $\begin{array}{l}\text { Обзор военных действий } \\
\text { в Китае }\end{array}$ & 6 & 8 января 1940 г. - 21 мая 1940 г. \\
\hline 4. & Война на Тихом океане & 2 & 6 июня 1942 г.- 15 ноября 1944 г. \\
\hline \multicolumn{2}{|c|}{ Итого } & 104 & 5 января 1940 г.- 15 ноября 1944 г. \\
\hline
\end{tabular}

Источник: таблица составлена авторами на основе изучения публикаций газеты «Боевая вахта» с января 1940 г. по ноябрь 1944 г.

Из табл. 1 следует, что в рассматриваемые годы материалы о событиях в Китае «Боевая вахта» давала в четырех рубриках, причем рубрика «Обзор военных действий в Китае» использовалась очень мало времени - менее пяти месяцев в 1940 г., рубрика 
«Японо-китайская война» - год и девять месяцев, рубрика «Военные действия в Китае» - свыше 4,5 лет. Появление в «Боевой вахте» специального раздела «Война на Тихом океане» связано с Тихоокеанским театром военных действий (1941-1945 гг.), охватившим Дальний Восток, Юго-Восточную Азию и Тихий океан, и с присоединением Китая к антифашистскому лагерю. Антияпонская война китайского народа стала частью войны в Азии, поэтому сообщения о ней давались в контексте Тихоокеанской войны. С точки зрения количества публикаций наиболее активно использовались рубрики «Военные действия в Китае» и «Японо-китайская война».

Газета «Боевая вахта» систематически информировала своих читателей о положении в Китае. В 1930-е годы китайское руководство постепенно осознавало, что агрессия Японии оказалась настолько серьёзной и опасной для нации в целом, что потребовалась война нации, создание единого национального антияпонского фронта. В 2005 г. Ху Цзиньтао в своей речи на конференции, посвящённой 60-летию победы Китая в народной антияпонской войне и победе во Второй мировой войне, особо подчеркнул: во время войны против Японии китайская нация сформировала национальный дух, основанный на патриотизме [4]. Это имело двоякое значение. С одной стороны, национальный дух послужил мощным источником мотивации антияпонских действий, а с другой, он способствовал развитию национального самосознания в послевоенную эпоху.

Во время войны Гоминьдан и Коммунистическая партия Китая создали антияпонский национальный единый фронт и консолидировали силы против японских захватчиков. В рассматриваемом нами издании можно найти, например, сообщения следующего рода: «В Северном Китае войска атаковали японские позиции восточнее Вэньси-Сясянь на юге провинции Шаньси и в нескольких местах разрушили шоссе... По непроверенным сведениям, 31 декабря [1939 г.] после усиленной воздушной бомбардировки японцев китайские войска были вынуждены вновь оставить Баотоу (провинция Суйюань)» [5].

В дополнение к новостям о действиях китайских войск Гоминьдана, сражавшихся на переднем фронте, газета в другой заметке информировала о боевых операциях Коммунистической партии Китая в тылу врага, в частности, о партизанах Четвертой армии, дислоцировавшихся на юге Китая. Так, ссылалась на «Чайна пресс», «Боевая вахта» сообщала, что «в треугольнике Шанхай - Нанкин - Ханчжоу действует китайская армия - около 100 тысяч хорошо подготовленных бойцов. В сражениях с нею между Ханчжоу, Цзясином и Хучожу японцы потеряли убитыми свыше 10 тыс. солдат [6]. Одновременно газета подчёркивала, что мощный удар по противнику наносят партизанские отряды: «В прошлом году в этом районе они провели не менее 200 сражений с японскими солдатами и отрядами марионеточного правительства. Было уничтожено около 50 железнодорожных и шоссейных мостов, захвачено около 100 японских военных катеров, бронемашин и автомобилей» [6]. 
Информацию, описывающую бои на переднем фронте в Китае, краснофлотская газета ТОФ часто давала в виде коротких депеш. Они позволяли держать дальневосточников в курсе событий антияпонской войны, борьбы китайского народа против японских агрессоров. Основным жанром публикуемых материалов являлась текущая хроника военных действий. Авторы выявили сотни таких сообщений. Они присутствовали практически в каждом газетном номере. Иногда в одном номере было несколько маленьких заметок о событиях антияпонской войны.

Текущая хроника военных действий могла сопровождаться поясняющими картами-схемами. Время от времени газеты публиковали фотоматериалы, но по ним очень трудно определить конкретных действующих лиц. Фотографии отражали события общего характера, например, «Отряд китайских войск», «Китайский пулемётный пост в Ханькоу» и др.

Формат больших статей «Боевая вахта» использовала в качестве обобщающих дополнений к непосредственному раскрытию реальной ситуации, к разностороннему анализу войны. Допустим, в статье «Три года героической борьбы китайского народа» [7] М. Степанов подробно показывал, как японские захватчики планировали и осуществляли план вторжения в Китай с 1937 г. по 1940 г., и то, как китайские войска и народ Китая сопротивлялись и срывали стратегические намерения Японии. Автор статьи выражал сочувствие решимости китайского народа вести борьбу до победы и подчёркивал, что «китайский народ в результате энергичной деятельности Чан Кайши и Коммунистической партии продолжает накапливать силы. Воодушевлённый идеей борьбы за свою независимость, уверенный в своей победе, Китай будет продолжать борьбу до полного освобождения и очищения своей страны от чужеземных захватчиков» [7].

В другой, не менее интересной статье под названием «Сырьевые ресурсы Японии» А. Ферсман [8] объяснял, что главной причиной начала Японией Тихоокеанской войны была её проблема со стратегическими запасами - нефтью, металлом, сталью и т.д. Проблема ярко обнаружилась в ходе агрессии против Китая. Япония - островное государство с ограниченным потенциалом, внешняя зависимость которого от импортных поставок нефти, металла, стали из-за рубежа, особенно из США, была весьма значительной. В связи с установлением США эмбарго на стратегические сырьевые товары, Япония могла воспользоваться только двумя вариантами развития событий: либо немедленно остановить войну против Китая, в которую уже вложила колоссальные средства, вследствие чего её внутренние резервы находились на грани истощения, либо найти новые источники снабжения страны ресурсами в целях их накопления для продолжения войны.

Интересен прогноз, сделанный «Боевой вахтой»: «...Недостаточность сырьевых ресурсов Японии и неизбежная экономическая блокада говорят о том, что японские империалисты, начав войну, могут рассчитывать в основном лишь на 
накопленные ресурсы. А это значит, что по мере развития войны эти ресурсы будут иссякать, а резервы США - расти. При таком положении вещей Япония, поскольку война будет, несомненно, длительной, обречена на неминуемое поражение» [8]. Сравнивая эти слова с произошедшими позднее историческими событиями, можно сделать вывод о правильности анализа ситуации и её развития, сделанными «Боевой вахтой».

Важной, по нашему мнению, была обзорная статья «Семь лет японо-китайской войны» [9], представлявшая картину главных событий в 1937-1944 гг. Автор материала М. Толченов рассказывал о трудностях, переживаемых Китаем в антияпонской войне. Китайский народ прошёл через большие лишения и жертвы, но он не сделался пассивным зрителем борьбы на разных фронтах. «Всё же военные действия, продолжающиеся на японо-китайском фронте уже в течение семи лет, - отмечалось в статье, - показывают, что надежды Японии на быстрое окончание войны в Китае не оправдались. Годы войны не сломили воли китайского народа, не поколебали его веры в успешный исход сопротивления. Китайский народ продолжает мужественно бороться за свою свободу и национальную независимость» [9].

В этой же статье автор рассказывал о коррупции и некомпетентности гоминьдановского правительства, его пассивной антияпонской позиции. Именно эти обстоятельства явились главными причинами, приведшими к массовому разгрому китайских войск на военном фронте провинций Хэнаня, Хунаня и Гуанси в 1944 г. В течение всей антияпонской войны правительство Гоминьдана не отказывалось от антикоммунистической политики. «Из имеющихся вооруженных сил [Гоминьдана], - подчёркивала газета, - значительная часть не принимает участия в боевых операциях против японских войск, а сосредоточена на севере страны, на границах особого пограничного района» [9].

Ранее эти же проблемы «Боевая вахта» поднимала в материале А. Кононенко «Война в Китае» [10].

«Боевая вахта» также знакомила читателей с тем, как японские захватчики обманывали китайских граждан, как заманили их в лагерь предателей и создавали марионеточные правительства на местных уровнях, то есть осуществляли политический заговор под лозунгом: «Закабалить Китай руками самих китайцев (以华治集》. В частности, информируя о вступлении режима Ван Цзинвэя в сговор с японскими захватчиками, «Боевая вахта» дала текст соглашения, подписанного между Ван Цзинвэем и японцами. Соглашение имело семь позиций, которые логически объединялись в две группы.

В первую группу входило то, что признавал режим Ван Цзинвэя, а именно он признавал Маньчжоу-Го и обещал сотрудничать с Японией и Маньчжоу-Го в экономической области и присоединиться к «антикоминтерновскому» пакту; признавал Северный Китай и Монголию специальными зонами обороны и экономическо- 
го развития; признавал за Японией экономические преимущества в нижнем течении реки Янцзы и её доминирующее положение на нескольких островах вдоль южного побережья Китая, включая острова Амой и Хайнань; Ван Цзинвэй признавал за Японией ряд привилегий в эксплуатации экономических ресурсов Китая и её право посылать своих советников в органы центрального правительства в ряде районов, вводить специальные тарифы и таможенные пошлины, благоприятствующие развитию японской торговли с Китаем.

Во второй группе декларировались права, которые предоставлялись японцам: право держать свои войска в стратегических районах Северного Китая и Внутренней Монголии, в долине Янцзы и на островах в южных водах; право держать в своих руках важнейшие для китайского государства объекты: железные дороги, авиационные линии, почту, телеграф, порты и водные пути в районах расположения их войск; режим Ван Цзинвэя обязывался немедленно возмещать Японии все расходы, связанные с войной против Китая [11].

Текст соглашения показывал предательские действия группы Ван Цзинвэя по отношению к китайскому государству, а также то, что так называемый режим Ван Цзинвэя являлся марионеточным и подконтрольным японским захватчикам. По сути дела, его действия передавали национальный суверенитет Китая японским захватчикам, что неизбежно должно было быть отвергнуто подавляющим большинством людей, придерживающихся позиций патриотизма, честности и справедливости.

Важно подчеркнуть, что «Боевая вахта» цитировала сообщения из китайских периодических изданий, оценивающих действия марионеточного режима Ван Цзинвэя. Так, газета «Чжунянжибао» [12] опубликовала рассмотренное выше соглашение [13], считая, что Ван Цзинвэй намерен отдать Китай Японии и что его действия предоставляют японским захватчикам право держать военные гарнизоны на территории Китая. Иными словами, Япония фактически оккупирует весь Китай и будет принуждать его враждебно относиться к СССР. Другая китайская газета «Дагунбао» - осуждала это со злой иронией [14], отмечая: «Теперь ясно, что разговоры о мире с Японией могут привести только к гибели страны. Ван Цзинвэю нужны были деньги, поэтому он подписал соглашение с Японией» [15]. Третья газета Китая - «Саотанбао» - указывала, что «Ван Цзинвэй давно стал изменником родины. Разумеется, что он не имеет никакого права подписывать соглашение от имени Китая» [15].

Вполне закономерно, действия по передаче группой Ван Цзинвэя национального суверенитета японским властям в Китае вызвали сильную обеспокоенность среди китайского населения. Об этом свидетельствовало вспыхнувшее 30 марта 1940 г. на территории французской концессии международного сеттльмента Шанхая движение против Ван Цзинвэя. 2 апреля 1940 г. «Боевая вахта» сообщила об этом событии [16]. Более того, газета указывала, что японские захватчики создали марионеточные режимы 
Юй Жуйхэн, Еланцева О. П. Антияпонская война китайского народа (1937-1945 гг.) на страницах газеты Тихоокеанского флота «Боевая вахта»

не только в оккупированных районах. В Северном Китае под контролем японцев существовали другие подобные режимы под руководством Лян Хунчжи и Ван Кэминя. Они не являлись единым целым, между ними происходила постоянная «грызня» [17]. На самом деле марионеточные режимы являлись инструментами, с помощью которых Япония стремились подчинить себе китайский народ, закабалить его.

С началом Тихоокеанской войны в 1941 г. Китай присоединился к лагерю союзников. В этой связи «Боевая вахта» не только сообщала о борьбе китайского народа с японскими захватчиками, но и освещала совместные военные действия Китая с союзниками. В частности, она информировала своих читателей о налётах американской авиации на территории Японии - собственные и оккупированные.

Таблицьа 2

«Боевая вахта» о действиях американской авиации против Японии

\begin{tabular}{|l|l|l|}
\hline № & \multicolumn{1}{|c|}{ Название материала } & \multicolumn{1}{|c|}{\begin{tabular}{c}
\multicolumn{1}{|c|}{ Дата публикации } \\
в «Боевой вахте»
\end{tabular}} \\
\hline 1. & $\begin{array}{l}\text { Налёт американских самолётов на Тяньцзинь } \\
\text { и Аньшань }\end{array}$ & 1944.1 августа \\
\hline 2. & Налёт американской авиации на Учань и Гонконг & 1944.3 августа \\
\hline 3. & Налёт американской авиации на Маньчжурию & 1944.30 сентября \\
\hline 4. & Налёт американской авиации на Мукден & 1944.23 декабря \\
\hline 5. & Налёт американской авиации на центральную Японию & 1944.26 декабря \\
\hline 6. & $\begin{array}{l}\text { Налёт американской авиации на оккупированный } \\
\text { Китай }\end{array}$ & 1945.20 января \\
\hline 7. & Налёт американской авиации на Кюсю & 1945.21 марта \\
\hline
\end{tabular}

Источник: таблица составлена авторами на основе изученных публикаций «Боевой вахты» за 1944-1945 гг.

Значение публикаций, перечисленных в табл. 2, заключалось в том, что они показывали географию налетов американской авиации, начиная с указания конкретных населённых пунктов (Тяньцзинь, Аньшань, Учань, Мукден, Гонконг) до таких обширных районов, как Маньчжурия, Центральная Япония, Кюсю и др. Интересно, что в сентябре 1945 г. «Боевая вахта», ссылаясь на агентство Рейтер, приводила данные людских потерь Японии в результате воздушных налётов авиации союзников: убито 241309 чел., ранено 313041 чел. Только в столице Японии погибло от налётов 88250 чел. [18].

Особое внимание «Боевая вахта» обратила на информирование своих читателей о военных действиях Советского Союза на территории трёх восточных провинций Китая, по-другому - в Маньчжурии (9 августа - 2 сентября 1945 г.). В совре- 
менной трактовке речь идет о советско-японской войне, ставшей важным историческим событием как для Советского Союза в рамках Второй мировой войны, так и для Китайской Республики в рамках антияпонской войны китайского народа. Это событие означало, что Советский Союз выполнил Ялтинское соглашение, объявил войну Японии в течение трех месяцев после капитуляции нацистской Германии.

Таблицุа 3

\section{Советско-японская война на страницах газеты «Боевая вахта»}

\begin{tabular}{|c|c|c|}
\hline № & Темы некоторых материалов & Дата публикации \\
\hline 1. & Пощады не будет & 1945. 13 августа \\
\hline 2. & Суркин П. Японские захватчики - наши злейшие враги & 1945. 14 августа \\
\hline 3. & $\begin{array}{l}\text { Минц И. Красная армия не первый раз бьёт японских } \\
\text { агрессоров }\end{array}$ & 1945. 15 августа \\
\hline 4. & Коровин Е. В Харбине & 1945. 23 августа \\
\hline 5. & $\begin{array}{l}\text { Твердяков В., Толмачев В., Шмавонян С. Хуньчунь, } \\
\text { маньчжурский город (Путевые заметки) }\end{array}$ & 1945. 23 августа \\
\hline 6. & Оживает китайский город. Муданьцзян & 1945.23 августа \\
\hline 7. & $\begin{array}{l}\text { К предстоящему подписанию акта о капитуляции } \\
\text { Японии }\end{array}$ & 1945. 25 августа \\
\hline 8. & $\begin{array}{l}\text { Важный этап в развитии советско-китайских } \\
\text { отношений }\end{array}$ & 1945. 30 августа \\
\hline 9. & Коровин Е. Японский фарс & 1945. 31 августа \\
\hline 10. & $\begin{array}{l}\text { Коровин Е. Мулин - Муданьцзян - Харбин } \\
\text { (Из фронтовых дневников) }\end{array}$ & 1945. 8 сентября \\
\hline 11 & Гофман К. Победа над Японией & 1945. 8 сентября \\
\hline 12 & Японские потери в войне & 1945. 11 сентября \\
\hline
\end{tabular}

Источник: таблица составлена авторами на основе изучения публикаций газеты «Боевая вахта» за август - сентябрь 1945 г.

Как показывает табл. 3, в «Боевой вахте» помещались разные материалы, раскрывавшие советско-японскую войну 1945 г., допустим, фронтовые дневники, путевые дневники. Небольшой материал «Пощады не будет» [19] был, по своей сути, карикатурой под красноречивым названием «Харакири» с эпиграфом следующего содержания: «На Хасане наломали вам бока / Били, били, говорили: ну, пока». Рисунок выполнил Н. Труфанов.

Два материала, приводимых в табл. 3 («К предстоящему подписанию акта о капитуляции Японии» [20] и «Японские потери в войне» [21]), говорят о привлечении «Боевой вахтой» материалов зарубежных агентств, в данном случае агентства Рейтер. 
В первом из них давалась информация генерала Макартура, который должен был подписать акт о капитуляции Японии от имени союзных держав. Он называл страны и их представителей, участвующих в этой церемонии. Во втором материале перечислялись потери торгового и морского флотов Японии, потери в живой силе и т.д. в войне.

В статье «Японские захватчики - наши злейшие враги» [22] капитан П. Суркин подчёркивал: «Наши цели ясны и благородны. Мы хотим навсегда покончить с угрозой японской агрессии на наших дальневосточных границах». Говоря об использовании Маньчжурии Японией в качестве плацдарма нападения на СССР, он оперировал такими фактами: если в начале 1941 г. в Маньчжурии находилось 10 японских пехотных дивизий, то к концу 1941 г. их стало 30; количество расквартированных здесь японских военных контингентов исчислялось в 1100000 чел., что превышало треть всей сухопутной армии Японии.

15 августа 1945 г. «Боевая вахта» поместила статью член-корреспондента Академии наук СССР историка И. И. Минца «Красная армия не первый раз бьёт японцев» [23]. Несколькими днями ранее этот материал был напечатан в главной военной газете СССР «Красная звезда» [24]. И. И. Минц напомнил развитие конфликта между Советским Союзом и Японией с 1918 г. по 1945 г.

Серию материалов «Боевой вахты» - «В Харбине», «Хуньчунь, маньчжурский город», «Оживает китайский город. Муданьцзян», «Мулин - Муданьцзян - Харбин», подготовленных специальными корреспондентами газеты Е. Коровиным, В. Твердяковым, В. Толмачевым, С. Шмавоняном [25; 26; 27; 28], газета объединяла под общим заголовком «Свободу и независимость несут советские воины китайцам и корейцам». В них рассказывалось об освобождении китайских городов советской армией, о том, как радостно и ликующе встречало бойцов местное население и как китайцы отзывались о времени японской оккупации, какие следы оставила оккупация. В каждом материале приводились удручающие примеры людской нищеты. Вместе с тем, Е. Коровин сообщал, что «в Харбине советского человека поражало смешение бедности и роскоши. В уличных потоках можно встретить рикшу и машину последней заграничной марки, телегу и фаэтон, коляску и старомодный трамвай с облупившейся краской... Торгуют магазины. И хотя цены на продукты очень высокие, и здешние жители приучены к экономии, сегодня в магазинах царит оживление. Особенно у магазинов, где продаются «слёзы вдовы Никитиной» - так в шутку в Харбине называли вино «Империалъ» - продукцию завода белоэмигрантки Никитиной» [25]. Практически через все материалы августа-сентября 1945 г. [29; 30 и др.] проходила картина японских солдат и офицеров, удручённых, шокированных военным поражением Японии.

Интересно, что от подготовки материала корреспондентами «Боевой вахты» до их публикации в газете проходили считанные дни. Сказывалась взаимовыручка военных. Так, в «Боевой вахте» за 23 августа 1945 г. встречаем помету к статьям: «Доставлено на самолетах старших лейтенантов Кирсанова и Шекунова». 
Одним из важнейших августовских [1945 г.] материалов «Боевой вахты» следует считать «Важнейший этап в развитии советско-китайских отношений» [31]. Это была перепечатка передовой статьи газеты «Правда» [32], сообщавшей о проходивших в Москве переговорах председателя СНК СССР И. В. Сталина и наркома иностранных дел СССР В. М. Молотова, с одной стороны, и китайского премьерминистра Сун Цзывэня и министра иностранных дел Китая Ван Шицзе, с другой стороны. 14 августа 1945 г. был подписан договор о дружбе и союзе между СССР и Китайской республикой, оцениваемый как значимый механизм укрепления отношений двух стран, действенное орудие борьбы за мир на Дальнем Востоке и прочный барьер против японской агрессии.

Договор конкретизировался в нескольких специальных соглашениях, направленных на укрепление безопасности обеих стран и предотвращение агрессии против них. Большое значение имело соглашение о Порт-Артуре, который был потерян Россией в результате поражения в русско-японской войне 1904-1905 гг. По документу 1945 г. Порт-Артур становился важнейшей советской военно-морской базой на Тихом океане, доступной для использования военными кораблями и торговыми судами только Китая и СССР [31]. Совместное использование Порт-Артура как военно-морской базы основывалось на следующих положениях:

- оборона базы вверялась правительством Китая правительству СССР, которое должно было создать необходимые сооружения, неся все соответствующие расходы;

- правительство СССР получало право содержать в районе Порт-Артура военные, военно-морские и воздушные силы и определять их дислокацию;

- гражданская администрация принадлежала Китаю;

- учреждалась военная комиссия в составе двух китайских и трёх советских представителей с советским председателем и китайским вице-председателем.

К соглашению о Порт-Артуре примыкало соглашение о порте Дальний [31], который объявлялся свободным портом для торговли и судоходства всех стран. Документом предусматривалась передача Советскому Союзу в аренду части пристаней и складских помещений Дальнего.

Важным дополнением к договору в области экономического сотрудничества СССР и Китая являлось соглашение о Китайской Чанчуньской железной дороге [31], которая создавалась путём объединения Китайской Восточной и Южно-Маньчжурской железных дорог. Право собственности на вновь создаваемую дорогу, как чисто коммерческое предприятие, принадлежало в равной степени Китаю и СССР.

Стоит обратить внимание, что информацию о межгосударственных документах СССР и Китайской республики, подписанных 14 августа 1945 г., передовица «Правды» анализировала 27 августа, то есть через 13 дней. За это время в советскояпонской войне очень многое изменилось. Оно позволяло центральной газете кон- 
статировать: документы подписаны в знаменательные дни, когда был разгромлен и вынужден к безоговорочной капитуляции японский империализм; очаг напряженности на Дальнем Востоке ликвидирован, а в его ликвидацию большой вклад внесли как СССР, так и Китай; советская армия в своём победоносном выступлении освободила Маньчжурию, Китай приобрел полный суверенитет над Маньчжурией.

Таким образом, главными темами публикаций «Боевой вахты» об антияпонской войне китайского народа являлись непосредственно боевые сражения армейских частей китайской армии и деятельность китайских партизанских отрядов; героическая борьба китайского народа; советско-японская война (август - сентябрь 1945 г.); военные операции японской армии; действия американской авиации против Японии; формирование и реализация агрессивной внешней политики Японии в Азии; стремление Японии нанести удар по экономике и культуре Китая, физически, морально и нравственно уничтожать китайский народ. Газета сообщала об используемых для этого механизмах: фактах предательства некоторых китайских политиков, марионеточных региональных правительствах, государстве Маньчжоу-Го.

Основным жанром публикуемых материалов являлась текущая хроника военных событий. Значимое место в газете занимали обзорно-аналитические статьи об антияпонской войне китайского народа, выполненные на материалах за несколько лет.

Отражение событий антияпонской войны китайского народа (1937-1945 гг.), тон и характер публикаций «Боевой вахты» соответствовали общей политической культуре Советского государства изучаемого времени и её информационной модели.

\section{Список литературы}

1. Китай не забывает дату начала японской оккупации - 18 сентября 1931 года. - URL: http://cctv.cntv.cn/2014/09/18/VIDE1411018565736992.shtml (дата обращения: 17 апреля 2020).

2. Важный этап в развитии советско-китайских отношений // Правда. 1945. - 27 августа.

3. Сталин - Кагановичу и Молотову, 23 сентября 1931 г. // Сталин и Каганович. Переписка. 1931-1936. - Москва, 2001. - С. 116.

4. 胡锦涛. 在纪念抗战胜利 60 周年大会上的讲话. // 人民日报. 2005 年 9 月 4 日. - Ху Цзиньтао. Речь на конференции, посвящённой 60-летию победы Китайской народной антияпонской войны // Жэнминьжибао. - 2005. - 4 сентября.

5. В Северном Китае // Боевая вахта. - 1940. - 5 января.

6. Действия китайской Четвёртой армии и партизан // Боевая вахта. 1940. - 5 января.

7. Степанов, М. Три года героической борьбы китайского народа // Боевая вахта. - 1940. - 4 июля. 
8. Ферсман, А. Сырьевые ресурсы Японии // Боевая вахта. - 1942. - 13 января.

9. Толченов, М. Семь лет японо-китайской войны // Боевая вахта. - 1944. 22 июля.

10. Кононенко, А. Война в Китае // Боевая вахта. - 1940. - 22 августа.

11. Разоблачение деятельности Ван Цзин-вэя // Боевая вахта. - 1940. - 26 января.

12. Китайские газеты о соглашении Ван Цзин-вэя // Боевая вахта. - 1940. 26 апреля.

13. 汪逆精卫卖国密约 // 中央日报. 1940年1月23日. - Секретное соглашение предателя Ван Цзинвэя // Чжунянжибао. - 1940. - 23 января.

14. 社评: 敌汪逆阴谋大暴露 // 大公报. 1940年1月23日. - Передовая статья: Разоблачение заговора предателя Ван Цзинвэя // Дагунбао. - 1940. - 23 января.

15. Китайские газеты о соглашении Ван Цзин-вэя // Боевая вахта. - 1940. 26 апреля.

16. Движение против Ван Цзин-вэя в Шанхае // Боевая вахта. - 1940. - 2 апреля.

17. Грызня в лагере Ванцзинвеецев // Боевая вахта. - 1940. - 17 апреля.

18. Японские потери в войне // Боевая вахта. - 1945. - 11 сентября.

19. Пощады не будет // Боевая вахта. - 1945. - 13 августа.

20. К предстоящему подписанию акта о капитуляции Японии // Боевая вахта. - 1945. - 25 августа.

21. Японские потери в войне // Боевая вахта. - 1945. - 11 сентября.

22. Суркин, П. Японские захватчики - наши злейшие враги // Боевая вахта. 1945. - 14 августа.

23. Минц, И. Красная армия не первый раз бьёт японских агрессоров // Боевая вахта. - 1945. - 15 августа.

24. Красная звезда. - 1945. - 10 августа.

25. Коровин, Е. В Харбине // Боевая вахта. - 1945. - 23 августа.

26. Твердяков, В. Хуньчунь, маньчжурский город (Путевые заметки) / В. Твердяков, В. Толмачев, С. Шмавонян // Боевая вахта. - 1945. - 23 августа.

27. Оживает китайский город. Муданьцзян // Боевая вахта. - 1945. - 23 августа.

28. Коровин, Е. Мулин - Муданьцзян - Харбин (Из фронтовых дневников) // Боевая вахта. - 1945. - 8 сентября.

29. Коровин, Е. Японский фарс // Боевая вахта. - 1945. - 31 августа.

30. Горфман, К. Победа над Японией // Боевая вахта. - 1945. - 8 сентября.

31. Важный этап в развитии советско-китайских отношений // Боевая вахта. - 1945. - 30 августа.

32. Важный этап в развитии советско-китайских отношений // Правда. 1945. - 27 августа. 


\section{References}

1. China does not forget the date of the beginning of the Japanese occupationSeptember 18, 1931. Available at: http://cctv.cntv.cn/2014/09/18/VIDE1411018565 736992.shtml (accessed 17 April 2020). (In Russian).

2. An important stage in the development of Soviet-Chinese relations. Pravda, 1945, August 27. (In Russian).

3. Stalin - Kaganovichu i Molotovu, 23 sentyabrya 1931 g. [Stalin to Kaganovich and Molotov, September 23, 1931]. Stalin i Kaganovich. Perepiska. 1931-1936 [Stalin and Kaganovich. Correspondence. 1931-1936]. Moscow, 2001, p. 116.

4. Hu Jintao. Speech at the Conference on the 60th Anniversary of the Victory of the Chinese People's Anti-Japanese War. Renminzhibao, 2005, September 4. (In Chinese).

5. In North China. Boevaya vakhta, 1940, January 5. (In Russian).

6. Actions of the Chinese Fourth Army and partisans. Boevaya vakhta, 1940, January 5. (In Russian).

7. Stepanov M. Tri goda geroicheskoi bor'by kitaiskogo naroda [Three years of the heroic struggle of the Chinese people]. Boevaya vakhta, 1940, July 4.

8. Fersman A. Syr'evye resursy Yaponii [Raw materials of Japan]. Boevaya vakhta, 1942, January 13.

9. Tolchenov M. Sem' let yapono-kitaiskoi voiny [Seven years of the JapaneseChinese war]. Boevaya vakhta, 1944, July 22.

10. Kononenko A. Voina v Kitae [War in China]. Boevaya vakhta, 1940, August 22.

11. Exposing the activities of Wang Ching-wei. Boevaya vakhta, 1940, January 26. (In Russian).

12. Chinese newspapers on the Wang Ching-wei agreement. Boevaya vakhta, 1940, April 26. (In Russian).

13. The secret agreement of the traitor Wang Jingwei. Zhongyangjibao, 1940, January 23. (In Chinese).

14. Editorial: Exposing the Conspiracy of the Traitor Wang Jingwei. Dagongbao, 1940, January 23. (In Chinese).

15. Chinese newspapers about the agreement of Wang Ching-wei. Boevaya vakhta, 1940, April 26. (In Russian).

16. Movement against Wang Ching-wei in Shanghai. Boevaya vakhta, 1940, April 2. (In Russian).

17. Bickering in the Wangjingwee camp. Boevaya vakhta, 1940, April 17. (In Russian).

18. Japanese losses in the war. Boevaya vakhta, 1945, September 11. (In Russian).

19. There will be no mercy. Boevaya vakhta, 1945, August 13. (In Russian). 
20. Towards the upcoming signing of Japan's surrender act. Boevaya vakhta, 1945, August 25. (In Russian).

21. Japanese losses in the war. Boevaya vakhta, 1945, September 11. (In Russian).

22. Surkin P. Yaponskie zakhvatchiki - nashi zleishie vragi [Japanese invaders our worst enemies]. Boevaya vakhta, 1945, August 14.

23. Mints I. Krasnaya armiya ne pervyi raz b'et yaponskikh agressorov [It is not the first time the Red Army beats Japanese aggressors]. Boevaya vakhta, 1945, August 15.

24. Krasnaya zvezda, 1945, August 10.

25. Korovin E. V Kharbine [In Harbin]. Boevaya vakhta, 1945, August 23.

26. Tverdyakov V., Tolmachev V. Shmavonyan S. Khun'chun', man'chzhurskii gorod (Putevye zametki) [Hunchun, Manchu city (Travel notes)]. Boevaya vakhta, 1945, August 23.

27. The Chinese city revives. Mudanjiang. Boevaya vakhta, 1945, August 23. (In Russian).

28. Korovin E. Mulin - Mudan'tszyan - Kharbin (Iz frontovykh dnevnikov) [Mulin - Mudanjiang - Harbin (From the front diaries)]. Boevaya vakhta, 1945, September 8.

29. Korovin E. Yaponskii fars [Japanese farce]. Boevaya vakhta, 1945, August 31.

30. Gorfman K. Pobeda nad Yaponiei [Victory over Japan]. Boevaya vakhta, 1945, September 8.

31. An important stage in the development of Soviet-Chinese relations. Boevaya vakhta, 1945, August 30. (In Russian).

32. An important stage in the development of Soviet-Chinese relations. Pravda, 1945, August 27. (In Russian).

Авторы благодарят Военно-исторический музей Тихоокеанского флота (г. Владивосток) за предоставленную возможность поработать с газетным фондом.

The authors would like to thank the Military Historical Museum of the Pacific Fleet (Vladivostok) for the opportunity to work with the newspaper fund. 